OPEN ACCESS

Edited by:

Jen-Tsung Chen,

National University of Kaohsiung,

Taiwan

Reviewed by:

Sezai Ercisli,

Atatürk University, Turkey

Hsuan Chen,

Oregon CBD, United States

*Correspondence: Wellington Ronildo Clarindo

well.clarindo@ufv.br

Specialty section:

This article was submitted to

Plant Breeding,

a section of the journa

Frontiers in Plant Science

Received: 05 December 2019

Accepted: 31 January 2020

Published: 04 March 2020

Citation:

Venial LR, Mendonça MAC, Amaral-Silva PM, Canal GB,

Passos ABRdJ, Ferreira $A$, Soares TCB and Clarindo WR (2020) Autotetraploid Coffea canephora and

Auto-Alloctaploid Coffea arabica From In Vitro Chromosome Set Doubling: New Germplasms for Coffea.

Front. Plant Sci. 11:154. doi: 10.3389/fp/s.2020.00154

\section{Autotetraploid Coffea canephora and Auto-Alloctaploid Coffea arabica From In Vitro Chromosome Set Doubling: New Germplasms for Coffea}

Lucimara Ribeiro Venial ${ }^{1}$, Maria Andréia Corrêa Mendonça ${ }^{2}$, Paulo Marcos Amaral-Silva ${ }^{1}$, Guilherme Bravim Canal ${ }^{3}$, Ana Beatriz Rocha de Jesus Passos ${ }^{3}$, Adésio Ferreira ${ }^{3}$, Taís Cristina Bastos Soares ${ }^{4}$ and Wellington Ronildo Clarindo ${ }^{5 *}$

1 Laboratório de Citogenética e Cultura de Tecidos Vegetais, Centro de Ciências Agrárias e Engenharias, Universidade Federal do Espírito Santo, Alegre, Brazil, 2 Laboratório de Biotecnologia, Instituto Federal Goiano-Campus Rio Verde, Rio Verde, Brazil, ${ }^{3}$ Laboratório de Biometria, Centro de Ciências Agrárias e Engenharias, Universidade Federal do Espírito Santo, Alegre, Brazil, ${ }^{4}$ Laboratório de Bioquímica e Biologia Molecular, Departamento de Farmácia e Nutrição, Centro de Ciências Exatas, Naturais e da Saúde, Universidade Federal do Espírito Santo, Alegre, Brazil, ${ }^{5}$ Laboratório de Citogenética e Citometria, Departamento de Biologia Geral, Centro de Ciências Biológicas e da Saúde, Universidade Federal de Viçosa, Viçosa, Brazil

Polyploidy is more than two chromosomal sets per nucleus, as the allotetraploid Coffea arabica. Due to allotetraploidy, C. arabica shows different phenotypes compare to diploid Coffea species, highlighting by beverage quality produced from its grains. Looking for the possibility of new phenotypes coupled with economic feature, considerable progress since 60's was reached for synthetic chromosome set doubling (CSD) in vitro, involving especially the antitubulin compounds, biological material, and used tissue culture pathway as the indirect somatic embryogenesis (ISE). Here, we aimed to regenerate autotetraploid and auto-alloctaploid plantlets of Coffea canephora and C. arabica, respectively, from a novel in vitro CSD procedure for Coffea. Exploring the ISE pathway, we treated the cellular aggregate suspensions (CAS) with 0.0 (control), $0.5,1.5$, or $2.5 \mathrm{mM}$ of colchicine solution for 48,72 , or $96 \mathrm{~h}$ and maintained in liquid medium under constant orbital shaking. After transferring the CAS to semisolid media for somatic embryo regeneration, we considered it as cellular mass. Mature cotyledonary somatic embryos were only regenerated from cellular masses treated with $2.5 \mathrm{mM} / 48 \mathrm{~h}$ and $2.5 \mathrm{mM} / 72 \mathrm{~h}$ for $\mathrm{C}$. canephora and with 0.5 $\mathrm{mM} / 48 \mathrm{~h}$ for $\mathrm{C}$. arabica. Evaluating the DNA ploidy level and the chromosome counting revealed that 36 (34.9\%) plantlets of $C$. canephora were autotetraploids $(4 \mathrm{C}=2.86 \mathrm{pg}$, $2 n=4 x=44)$ and $61(21.1 \%)$ of $C$. arabica were auto-alloctaploids $(4 C=5.24$ pg, $2 n=$ $8 \mathrm{x}=88$ ). The CSD procedure, exploring the CAS proliferation and ISE pathway, promoted whole-genome duplication and resulted in a relatively high number of solid polyploids of both Coffea species. Due to distinct responses, DNA sequence fidelity (genetic) and global level of 5-methylcytosine (epigenetic) were evaluated. We observed that the increase of 5methylcytosine levels was associated with somatic embryo regeneration from cells 
showing DNA sequence fidelity for the tested SSR primers. In conclusion, the adopted procedure for in vitro CSD is reproducible for induction, regeneration and propagation of Coffea polyploids and potentially other shrubbery and woody species. In view of the novelty of this procedure to generate new germplasm, we show the key issues and the steps of the CSD procedure.

Keywords: coffee, polyploidy, plant tissue culture, flow cytometry, cytogenetics, whole-genome duplication

\section{HIGHLIGHTS}

We established a novel chromosome set doubling procedure for Coffea treating cellular aggregate suspensions with colchicine. From this procedure, new Coffea canephora autotetraploids and Coffea arabica auto-alloctaploids were regenerated.

\section{INTRODUCTION}

Polyploidization leads to more than two complete chromosome sets per nucleus in a cell, naturally occurring through autopolyploidy or allopolyploidy (Stebbins, 1947). As a result of "omic" changes (genomic, epigenomic, transcriptomic, and metabolomic), polyploids may exhibit new physiological, morphological and reproductive phenotypes and/or traits (Sattler et al., 2016; Li et al., 2019; Iannicelli et al., 2020). Because of this, polyploidy has been considered an important trigger in plant diversification and evolution (Soltis et al., 2009; Iannicelli et al., 2020), including the saltational speciation (Mallet, 2007; Iannicelli et al., 2020).

The impact of natural polyploidy on plant diversity and evolution, but also in worldwide economy and breeding programs, have inspired several research groups to establish different strategies for synthetic polyploidization through chromosome set doubling (CSD). In an agronomic scenario, the ex vitro and in vitro procedures to induce synthetic polyploidy lead to new and/or improved germplasms, enhancing the breeding programs of crop, ornamental, medicinal and forest species (Dhooghe et al., 2011; Sattler et al., 2016; Iannicelli et al., 2020). Synthetic polyploids have been obtained mainly from CSD in in vitro environments following Murashige and Nakano (1966), under controlled physical and chemical conditions. Biological material showing proliferative cells, mainly shoot tips, is exposed to the antitubulinic agent (e.g., colchicine, oryzalin, trifluralin, amiprophos-methyl) added to the tissue culture medium. These compounds prevent the mitotic or meiotic spindle microtubule (fuse) formation through binding to $\alpha$ - and/or $\beta$ tubulin (Planchais et al., 2000). Due to this cytotoxic effect, the sister chromatids (mitotic anaphase, meiotic anaphase II) and homologues chromosomes (meiotic anaphase I) disjunction as well as the cytokinesis do not occur, resulting in cells with duplicated chromosome set. Regarding the in vitro strategies, the chromosome set has been successfully duplicated for trees and shrubs, like Acacia dealbata Link., Acacia mangium Willd.
(Blakesley et al., 2002), Platanus acerifolia (Ait.) Willd. (Liu et al., 2007), Jatropha curcas L. (de Oliveira et al., 2013), Ziziphus jujuba Mill. (Shi et al., 2015), Eriobotrya japonica (Thunb.) Lindl. (Blasco et al., 2015), allotriploid "Híbrido de Timor" (Coffea canephora Pierre ex A. Froehner $x$ Coffea arabica L., Sanglard et al., 2017), Eucalyptus grandis W. Hill ex Maiden, Eucalyptus urophylla S. T. Blake, Eucalyptus benthamii Maiden \& Cambage, and homoploid E. urophylla $x$ E. grandis (Silva et al., 2019).

In order to expand the applicability, improvements have been made to solve the main bottlenecks of the in vitro CSD procedure: low rate of solid polyploids and high rate of mixoploids, as well as propagule mortality. Nowadays, the more promising in vitro procedure associates the indirect somatic embryogenesis (ISE) pathway with the antitubulin agent treatment. This in vitro pathway is based on somatic embryo recovery-the possibility of regenerating a plantlet from a single cell (Stewart et al., 1958)_which maximizes the occurrence of only solid polyploids from CSD exploring the ISE (Wu and Mooney, 2002; Dutt et al., 2010; Acanda et al., 2015; Sanglard et al., 2017).

Pro-embryogenic cells of friable calli in semisolid medium (Wu and Mooney, 2002; Petersen et al., 2003; Zhang et al., 2007; Sanglard et al., 2017) or of cellular aggregate suspensions (CAS) in liquid medium (Dutt et al., 2010; Acanda et al., 2015) have been exposed to different antitubulin agents for different times and concentrations. CSD was performed from semisolid system for Spathiphyllum wallisii Regel (Eeckhaut et al., 2004), Citrus L. (Wu and Mooney, 2002; Petersen et al., 2003; Zhang et al., 2007), homoploid Vitis x Muscadinia (Xie et al., 2015), anorthoploid Coffea "Híbrido de Timor" (Sanglard et al., 2017), Lilium distichum Nakai, and Lilium cernuum Komar (Fu et al., 2019). Differently, Dutt et al. [(2010), for Citrus reticulata Blanco] and Acanda et al. [(2015), for Vitis vinifera L. "Mencía”] conducted the CSD from CAS, which they established from friable calli propagated in liquid medium. CAS show a high cell proliferation rate (van Boxtel and Berthouly, 1996) that is the feedstock for CSD. The gradient of nutrients in the liquid medium is considered another advantage over semisolid system (Dutt et al., 2010), increasing cell contact with the tissue culture compounds and with the antitubulin used for CSD.

Variations in the ISE response have been observed after treatment with antitubulin agents, as the rate of somatic embryos and plantlets (responsive or unresponsive) recovered from the friable calli or CAS (Wu and Mooney, 2002; Zhang et al., 2007; Sanglard et al., 2017). The causes of these variations can be associated with the in vitro conditions, the occurrence of somaclonal variation during the ISE pathway and/or the 
cytotoxic effect of the antitubulin treatment that involves a pulse using different compounds and concentrations (Dhooghe et al., 2011). Thus, genetic (SSR markers) and epigenetic (global methylated cytosine) features are appointed as possible factors that interfere in the somatic embryo and plantlet regeneration (Dutt et al., 2010). Therefore, these aspects should be investigated in order to understand the distinct ISE responses.

Owing to the new genomic and phenomic features of the polyploids in relation to their ancestors, there is great interest to achieve synthetic polyploids. The aim of this work was to establish a new procedure for CSD from CAS of the agronomic relevant Coffea species C. canephora and C. arabica. Additionally, we evaluate the DNA sequence stability (SSR markers) and epigenetic (5-methylcytosine) level to find possible causes for the varying ISE responses. We choose $C$. canephora and $C$. arabica because of the previously established ISE for these species by our research group (Sanglard et al., 2019). Besides, C. canephora and C. arabica are relevant for the economy of some countries, like Brazil, Vietnam, Colombia, Mexico, Indonesia, India, Guatemala, Uganda, and Ethiopia. The grains produced by C. arabica represent $70-75 \%$ of the exported coffee for Brazil, and $25-30 \%$ by C. canephora. Thus, we also expected to provide new C. canephora and C. arabica polyploid germplasms for future breeding approaches involving selection of the individuals based on their grain production, coffee beverage quality and tolerance and resistance to abiotic and biotic stresses, as well as for crossing with other Coffea.

\section{MATERIALS AND METHODS}

\section{Plant Material}

One C. canephora plantlet, which has been propagated in an in vitro germplasm bank (Universidade Federal do Espírito Santo, Espírito Santo, Brazil), and one C. arabica plant, which has been maintained in a greenhouse bank (Universidade Federal de Viçosa, Minas Gerais, Brazil), were used as explant donor plants. Chromosome number, ploidy level and DNA content of the explant donor plants were confirmed as $2 \mathrm{n}=2 \mathrm{x}=22$ chromosomes and $2 \mathrm{C}=1.43 \mathrm{pg}$ for $C$. canephora, and $2 \mathrm{n}=$ $4 \mathrm{x}=44$ chromosomes and $2 \mathrm{C}=2.62 \mathrm{pg}$ for $C$. arabica. These Coffea crops were chosen due to agronomic and evolutive relevance. C. canephora is a diploid species with $2 \mathrm{n}=2 \mathrm{x}=22$ chromosomes and 2C nuclear DNA content of $1.43 \mathrm{pg}$, and $C$. arabica is a true allotetraploid that possesses $2 \mathrm{n}=4 \mathrm{x}=44$ chromosomes and 2C $=2.62 \mathrm{pg}$ (Sanglard et al., 2019). C. arabica is the only polyploid species of the Coffea genus, which was probably originated from crossing between the diploid species Coffea eugenioides S. Moore and C. canephora. Besides the karyotype, the divergences between these species also include the reproductive mechanism (C. canephora is allogamous, like the other diploid Coffea species, and C. arabica is autogamous, $\mathrm{Yu}$ et al., 2011), morphological and physiological aspects (Charrier and Berthaud, 1985), and commercial relevance mainly associated to the beverage quality of coffee (Farah and Donangelo, 2006).

\section{Friable Calli Induction and Cellular Aggregate Suspensions Establishment}

We collected and disinfected leaves of Coffea arabica according to Sanglard et al. (2019) before inoculation. We excised five leaf fragments of $1 \mathrm{~cm}^{2}$ from both species and inoculated them in M1 medium (Table 1) in $60 \times 15 \mathrm{~mm}$ Petri dishes. The culture was conducted in the dark at $25 \pm 2{ }^{\circ} \mathrm{C}$ for friable calli induction. After 60 days, $0.5 \mathrm{~g}$ of friable calli was transferred to $125 \mathrm{ml}$ Erlenmeyers containing $30 \mathrm{ml}$ of M2 medium (Table 1). The Erlenmeyers were maintained in the dark at $25 \pm 2^{\circ} \mathrm{C}$ on a 100 rpm orbital shaker. For establishment of the CAS, the material was subcultured every 15 days into a fresh medium, respecting the $0.5 \mathrm{~g}$ of cellular aggregates per Erlenmeyer. All procedures were performed under aseptic conditions.

\section{Chromosome Set Doubling and Plantlet Recovering}

After the fourth subculture, the CAS were treated with colchicine, an alkaloid compound isolated from Colchicum autumnale L. seeds and bulbs (Planchais et al., 2000). We applied the colchicine treatment 7 days after the fourth subculture, according to growth curves of the C. canephora and C. arabica CAS (van Boxtel and Berthouly, 1996). For this, we added filter-sterilized colchicine solution to each Erlenmeyer: 0.0 (control), 0.5, 1.5, and $2.5 \mathrm{mM}$, respectively for each treatment. The CAS were maintained under colchicine treatment in the dark, on a $50 \mathrm{rpm}$ orbital shaker at $25 \pm 2^{\circ} \mathrm{C}$ for 48, 72, and $96 \mathrm{~h}$. One Erlenmeyer referred to each treatment (colchicine/time), adding up to 12 in total. After colchicine

TABLE 1 | Tissue culture media used for friable calli induction (M1), CAS establishment (M2), CSD (M2), somatic embryo (M3 and M4) and plantlet regeneration (M5) of $C$. canephora and $C$. arabica.

\begin{tabular}{|c|c|c|c|c|c|}
\hline \multirow[t]{2}{*}{ Components } & \multicolumn{5}{|c|}{ Medium } \\
\hline & M1 & M2 & M3 & M4 & M5 \\
\hline MS $\left(\right.$ Sigma $\left.{ }^{\circledR}\right)$ & $2.15 \mathrm{~g} \mathrm{~L}^{-1}$ & $2.15 \mathrm{~g} \mathrm{~L}^{-1}$ & $4.30 \mathrm{~g} \mathrm{~L}^{-1}$ & $4.30 \mathrm{~g} \mathrm{~L}^{-1}$ & $4.30 \mathrm{~g} \mathrm{~L}^{-1}$ \\
\hline $\begin{array}{l}\text { Gamborg's B5 } \\
\text { vitamins }\end{array}$ & $10 \mathrm{ml} \mathrm{L}^{-1}$ & $10 \mathrm{ml} \mathrm{L}^{-1}$ & $10 \mathrm{ml} \mathrm{L}^{-1}$ & $10 \mathrm{ml} \mathrm{L}^{-1}$ & $10 \mathrm{ml} \mathrm{L}^{-1}$ \\
\hline Sucrose $\left(\right.$ Sigma $\left.{ }^{\circledR}\right)$ & $30 \mathrm{~g} \mathrm{~L}^{-1}$ & $30 \mathrm{~g} \mathrm{~L}^{-1}$ & $30 \mathrm{~g} \mathrm{~L}^{-1}$ & $30 \mathrm{~g} \mathrm{~L}^{-1}$ & $30 \mathrm{~g} \mathrm{~L}^{-1}$ \\
\hline $\begin{array}{l}\text { L-cysteine } \\
\left(\text { Sigma }^{\circledR}\right)\end{array}$ & $0.08 \mathrm{~g} \mathrm{~L}^{-1}$ & $0.04 \mathrm{~g} \mathrm{~L}^{-1}$ & $0.04 \mathrm{~g} \mathrm{~L}^{-1}$ & $0.04 \mathrm{~g} \mathrm{~L}^{-1}$ & $0.04 \mathrm{~g} \mathrm{~L}^{-1}$ \\
\hline $\begin{array}{l}\text { Malt extract } \\
\left(\text { Sigma }^{\circledR}\right)\end{array}$ & $0.4 \mathrm{~g} \mathrm{~L}^{-1}$ & $0.4 \mathrm{~g} \mathrm{~L}^{-1}$ & $0.4 \mathrm{~g} \mathrm{~L}^{-1}$ & $0.4 \mathrm{~g} \mathrm{~L}^{-1}$ & $0.4 \mathrm{~g} \mathrm{~L}^{-1}$ \\
\hline $\begin{array}{l}\text { Casein } \\
\text { hydrolysate } \\
\left(\text { Sigma }^{\circledR}\right)\end{array}$ & $0.1 \mathrm{~g} \mathrm{~L}^{-1}$ & $0.1 \mathrm{~g} \mathrm{~L}^{-1}$ & $0.1 \mathrm{~g} \mathrm{~L}^{-1}$ & $0.1 \mathrm{~g} \mathrm{~L}^{-1}$ & $0.1 \mathrm{~g} \mathrm{~L}^{-1}$ \\
\hline 2,4-D $\left(\right.$ Sigma $\left.{ }^{\circledR}\right)$ & $9.06 \mu \mathrm{M}$ & $9.06 \mu \mathrm{M}$ & - & - & - \\
\hline BAP $\left(\right.$ Sigma $\left.^{\circledR}\right)$ & $4.44 \mu \mathrm{M}$ & $4.44 \mu \mathrm{M}$ & $4.44 \mu \mathrm{M}$ & $4.44 \mu \mathrm{M}$ & - \\
\hline $\mathrm{GA}_{3}\left(\mathrm{Sigma}^{\circledR}\right)$ & - & - & - & - & $2.89 \mu \mathrm{M}$ \\
\hline $\begin{array}{l}\text { Phytagel } \\
\left(\text { Sigma }^{\circledR}\right)\end{array}$ & $2.8 \mathrm{~g} \mathrm{~L}^{-1}$ & - & $2.8 \mathrm{~g} \mathrm{~L}^{-1}$ & $2.8 \mathrm{~g} \mathrm{~L}^{-1}$ & $2.8 \mathrm{~g} \mathrm{~L}^{-1}$ \\
\hline $\begin{array}{l}\text { Activated } \\
\text { charcoal }\left(\text { Isofar }^{\circledR}\right)\end{array}$ & - & - & $2.0 \mathrm{~g} \mathrm{~L}^{-1}$ & $4.0 \mathrm{~g} \mathrm{~L}^{-1}$ & - \\
\hline $\mathrm{pH}$ & 5.6 & 5.6 & 5.6 & 5.6 & 5.6 \\
\hline
\end{tabular}

MS, Murashige and Skoog (1962); Gamborg's B5 vitamins, Gamborg et al. (1968); 2,4-D, 2,4-dichlorophenoxyacetic acid; BAP: 6-benzylaminopurine; $G A_{3}$, gibberellic acid. Culture media were sterilized in an autoclave at $121^{\circ} \mathrm{C}$ and $1.5 \mathrm{~atm}$ for $20 \mathrm{~min}$. 
exposition, the CAS of each Erlenmeyer was separately filtered through a $40 \mu \mathrm{m}$ cell strainer (BD Falcon ${ }^{\mathrm{TM}}$ ), and carefully washed with at least $50 \mathrm{ml}$ of autoclaved $\mathrm{dH}_{2} \mathrm{O}$ for residual elimination of colchicine (Figure 1). Cellular aggregates of each Erlenmeyer were subdivided in $60 \times 15 \mathrm{~mm}$ Petri dishes containing M3 or M4 medium (Table 1). After transferring the CAS to semisolid medium, the cellular aggregates were denominated as cellular mass. After regeneration of somatic embryos, only the mature cotyledonary somatic embryos (MCSE) were transferred to tubes containing M5 medium for germination (Table 1).

\section{Ploidy Level of the Recovered Plantlets}

Initially, we determined the DNA ploidy level of the regenerated C. canephora and C. arabica plantlets from nuclei suspensions extracted from leaf fragments $\left(\sim 1 \mathrm{~cm}^{2}\right)$ by chopping (Galbraith et al., 1983) and staining according to Otto (1990) and PraçaFontes et al. (2011). Nuclei suspensions obtained from leaves of the explant donor C. canephora and C. arabica were used as control for DNA ploidy level determination. The suspensions were analyzed with a Partec PAS ${ }^{\circledR}$ cytometer (Partec ${ }^{\circledR} \mathrm{GmbH}$, Münster, Germany).

In addition, roots were excised and treated according to Sanglard et al. (2017) to determine the $2 \mathrm{n}$ chromosome number of the plantlets previously screened by flow cytometry. From these roots, we prepared slides by cell dissociation and air-drying. All slides were stained with $5 \%$ Giemsa for $20 \mathrm{~min}$, washed two times in $\mathrm{dH}_{2} \mathrm{O}$ and analyzed under a Nikon Eclipse Ci-S microscope (Nikon). Prometaphases and metaphases were captured using 100x objective and a CCD camera (Nikon Evolution $^{\mathrm{TM}}$ ) coupled to a Nikon 80i microscope (Nikon).
A

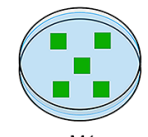

M1

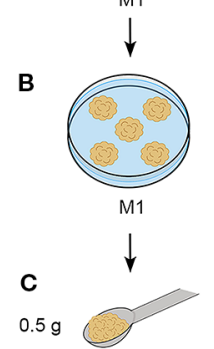

D

1

E

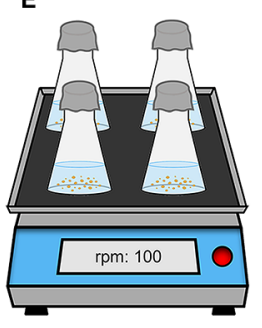

I<smiles>O[C@H]1C2CC3CC1C3C2</smiles>

H

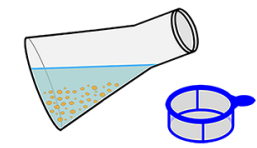

$\uparrow 48,72$ or $96 \mathrm{~h}$

G

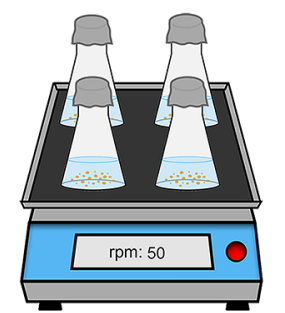

F

$\uparrow$

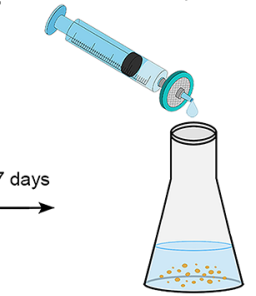

$\mathrm{M} 2+$ Colch

$0.0,0.5,1.5$ or $2.5 \mathrm{mM}$

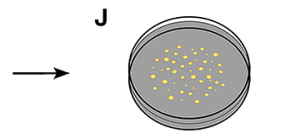

M3

K

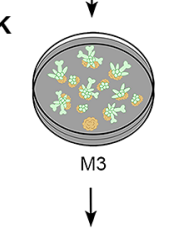

L
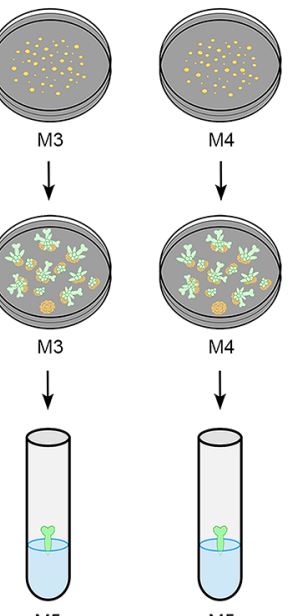

$\downarrow$

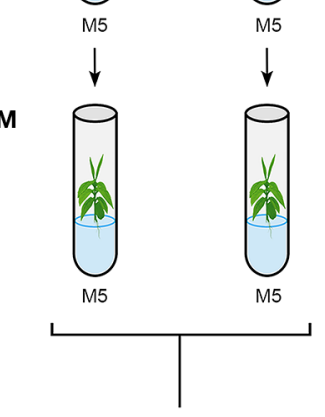

$\begin{array}{cr}\text { Flow cytometry } & \text { SSR markers } \\ \text { and } & \text { and } \\ \text { Cytogenetics } & 5-\mathrm{mC}\end{array}$

FIGURE 1 | Novel procedure for CSD from CAS treated with colchicine. (A) Coffea leaf fragment explants $\left(\sim 1 \mathrm{~cm}^{2}\right)$ in M1 medium (Table 1). (B) Friable calli after $\sim 30$ days in M1. (C, D) $0.5 \mathrm{~g}$ of friable calli in $125 \mathrm{ml}$ Erlenmeyers containing $30 \mathrm{ml}$ of M2 medium (Table 1). (E) CAS on orbital shaker at $100 \mathrm{rpm}$. (F) Filter sterilized colchicine solution addition at different concentrations after seven days, according growth curve reported for Coffea (van Boxtel and Berthouly, 1996). (G) CAS under colchicine treatment for distinct times on orbital shaker at $50 \mathrm{rpm}$. (H, I) Careful and continous washing of the CAS with $50 \mathrm{ml}$ sterile $\mathrm{dH} \mathrm{H}_{2} \mathrm{O}$. (J) Cellular mass (CM) in M3 or M4 medium (Table 1). (K) CM showing C. canephora or C. arabica globular, heart, torpedo and cotyledonary embryos in M3 and M4. CM samples of "j" and "I" were collected to evaluate and compare the DNA sequence variability and 5-methylcytosine level. (L) MCSE in M5 medium (Table 1). For C. arabica, these embryos were obtained after 120 days, and for C. canephora after 180 days. (M) Regenerated plantlets of the two Coffea species, of which we excised leaves for DNA ploidy level determination and root meristems for chromosome counting. 


\section{DNA Sequence Stability and 5- Methylcytosine Level}

Due to different responses obtained during the somatic embryo recovery in M3 and M4, DNA sequence stability (SSR markers) and 5-methylcytosine level (5-mC\%) were evaluated in order to identify genetic (SSR markers) and epigenetic (5-mC\%) differences related to in vitro responses. For this, besides of leaf of the explant donor plants, the following DNA samples of the cellular mass were used: (a) not colchicine-exposed (control friable calli of the M1), (b) colchicine-exposed and without somatic embryos, and (c) colchicine-exposed and with MCSE, totalling to 32 samples for DNA sequence stability and 21 for 5$\mathrm{mC} \%$ analyses (Table S1). Because at least $30 \mu \mathrm{g}$ of genomic DNA are necessary to accomplish the $5-\mathrm{mC} \%$ measurement, cellular masses of the same treatment and in vitro response $(a, b$, or c-above) were put together. Genomic DNA was extracted from the explant donor Coffea plants and the cellular mass and macerated in MagNALyser (Roche ${ }^{\circledR}$, Germany) for $70 \mathrm{~s}$ at 6,300 rpm (Doyle and Doyle, 1990), with addition of $7.5 \mathrm{M}$ $\mathrm{C}_{2} \mathrm{H}_{3} \mathrm{O}_{2} \mathrm{NH}_{4}$ and excluding the overnight period for DNA precipitation. DNA purity and concentration were estimated using NanoDrop (Thermo Scientific ${ }^{\circledR}$ 2000c).

DNA sequence stability was evaluated employing ten SSR primers (SSR Ca002, SSRCa021, SSRCa045, SSRCa091, SSRCa006, SSRCa084, SSRCa085, SSRCa087, SSRCa088, and SSRCa095) developed and validated for C. arabica (Missio et al., 2009). PCR reactions were performed in a final volume of $15 \mu \mathrm{L}$ composed of: $3 \mu \mathrm{L}$ of $5 \times$ buffer, $1.5 \mathrm{mM}$ of dNTPs, 0.2 $\mu \mathrm{M}$ of primers, $50 \mathrm{ng}$ of DNA, $1.6 \mathrm{mM}$ of $\mathrm{MgCl}_{2}, 1 \mathrm{U}$ of Taq DNA polymerase, and sufficient quantity of $\mathrm{dH}_{2} \mathrm{O}$ to $15 \mu \mathrm{l}$. Amplifications were carried out in a Bio-Rad ${ }^{\circledR}$ 96-Well Thermal Cycler $\mathrm{C} 1000^{\mathrm{TM}}$ by touchdown PCR procedure, as performed by Sanglard et al. (2017) for allotriploid and hexaploid "Híbrido de Timor". PCR products were submitted to electrophoresis on $10 \%$ polyacrylamide gel in $1 \mathrm{X}$ TBE buffer for $4 \mathrm{~h}$ at $100 \mathrm{~V}$. The gels were stained with ethidium bromide solution $\left(0.25 \mathrm{mg} \mathrm{ml}^{-1}\right)$ for $20 \mathrm{~min}$, and photo-documented in a Bio-Rad Molecular Imager ${ }^{\circledR}$ Gel Doc TM using the Image Lab program. The allele forms were tabulated considering the number and position of the bands.

Global 5-mC\% was measured through high-performance liquid chromatography (HPLC) using $30 \mu \mathrm{g}$ of DNA diluted in sterile $\mathrm{dH}_{2} \mathrm{O}$ for $100 \mu \mathrm{l}$ of solution. DNA samples were hydrolyzed with $50 \mu \mathrm{l}$ of $70 \%$ perchloric acid at $100^{\circ} \mathrm{C}$ for $1 \mathrm{~h}$ and the pH 4 (Chen et al., 2013). The solutions were analyzed in Prominence HPLC (Shimadzu ${ }^{\circledR}$, Japan). The global 5-mC\% of each sample was determined by comparison with standards of cytosine $(\mathrm{C})$ and 5-mC for HPLC (Sigma $\left.{ }^{\circledR}\right)$. The global 5-mC\% in the DNA was calculated by $\% 5-\mathrm{mC}=[5-\mathrm{mC} /(\mathrm{C}+5-\mathrm{mC})]$ $\times 100$.

\section{Statistical Analysis}

The total number of MCSE was compared by $F$ test $(P \leq 0.05)$ and represented in graphics. Cellular masses [(a) not colchicineexposed (control-friable calli of the M1), (b) colchicine-exposed and without somatic embryos and (c) colchicine-exposed and with MCSE] were compared in relation to their DNA sequence stability and their global 5-mC\%. A contingency table was generated considering all allele forms found for each SSR primer and for each defined cellular mass. After analysis of variance (ANOVA), we performed a correspondence analysis from the contingency table to verify the relation between the allele forms and cellular masses. The mean global 5-mC\% values were compared by ANOVA, followed by Dunnett's test $(P \leq$ $0.05)$. Statistical comparisons were performed using the software R (R CORE TEAM, Version 3.1.1, 2014-07-10).

\section{RESULTS}

\section{Indirect Somatic Embryogenesis Response}

After 90 days in M1 (Table 1), the mean number of responsive explants, which were defined by leave fragments with friable calli, was 1.07 for C. canephora and 2.37 for C. arabica. In M2 (Table 1), CAS were established from friable calli of the two Coffea species after the third subculture, equivalent to 45 days. So, the CSD procedure was conducted in the seventh day during the fourth subculture. After transferring the cellular aggregates to M3 or M4, they were denominated cellular mass (Figure 1).

C. canephora somatic embryos were regenerated from cellular mass treated with $2.5 \mathrm{mM} / 48 \mathrm{~h}$ colchicine and maintained in M3 or M4 and $2.5 \mathrm{mM} / 72 \mathrm{~h}$ colchicine in M3. For C. arabica, somatic embryos were recovered only from $0.5 \mathrm{mM} / 72 \mathrm{~h}$ colchicine in M3 or M4 (Figure 2). The cellular mass of these Coffea species presented globular somatic embryos (Figure 3A), which were converted in heart (Figure 3B), torpedo (Figure 3C) and cotyledonary stages (Figures 3D-F). The cotyledonary somatic embryos matured into MCSE (Figure 3F). Somatic embryos in different development stages were recorded in the same responsive cellular mass, evidencing an asynchronized ISE response (Figures $\mathbf{2}$ and 3). The responsive cellular masses were statistically identical in relation to somatic embryo number.

In M3 and M4, we recovered 324 MCSE for C. arabica after 90 days and 76 for $C$. canephora after 120 days (Table 2, Figure S1). Thus, the regeneration response occurred in different moments for the two Coffea species, the colchicine treatments (time and concentration) and for M3 and M4 media. We counted a total of 878 MSCE in the experiment, of which 621 were from C. arabica and 257 from C. canephora. The plantlets were recovered gradually from the MCSE in M5 medium (Table 1) after 60 days, resulting in 392 (44.6\%) plantlets out of which 103 plantlets belonged to $C$. canephora and 289 to C. arabica (Table 1). This reduced number of plantlets in relation to MCSE is due to failure or inadequate morphological development of the root and shoot. The cellular masses showed an almost continuous production of somatic embryos for both species, over a time span of more than one year, with potential for plantlet recovery over several months. However, we only regarded embryos until 150 days in M3 or M4 in this study.

\section{Plantlet Screening for Chromosome Set Doubling}

DNA ploidy level was determined for individual plantlet (392 plantlets, Table 2, Figure S1) upon comparison with the $G_{0} / G_{1}$ 


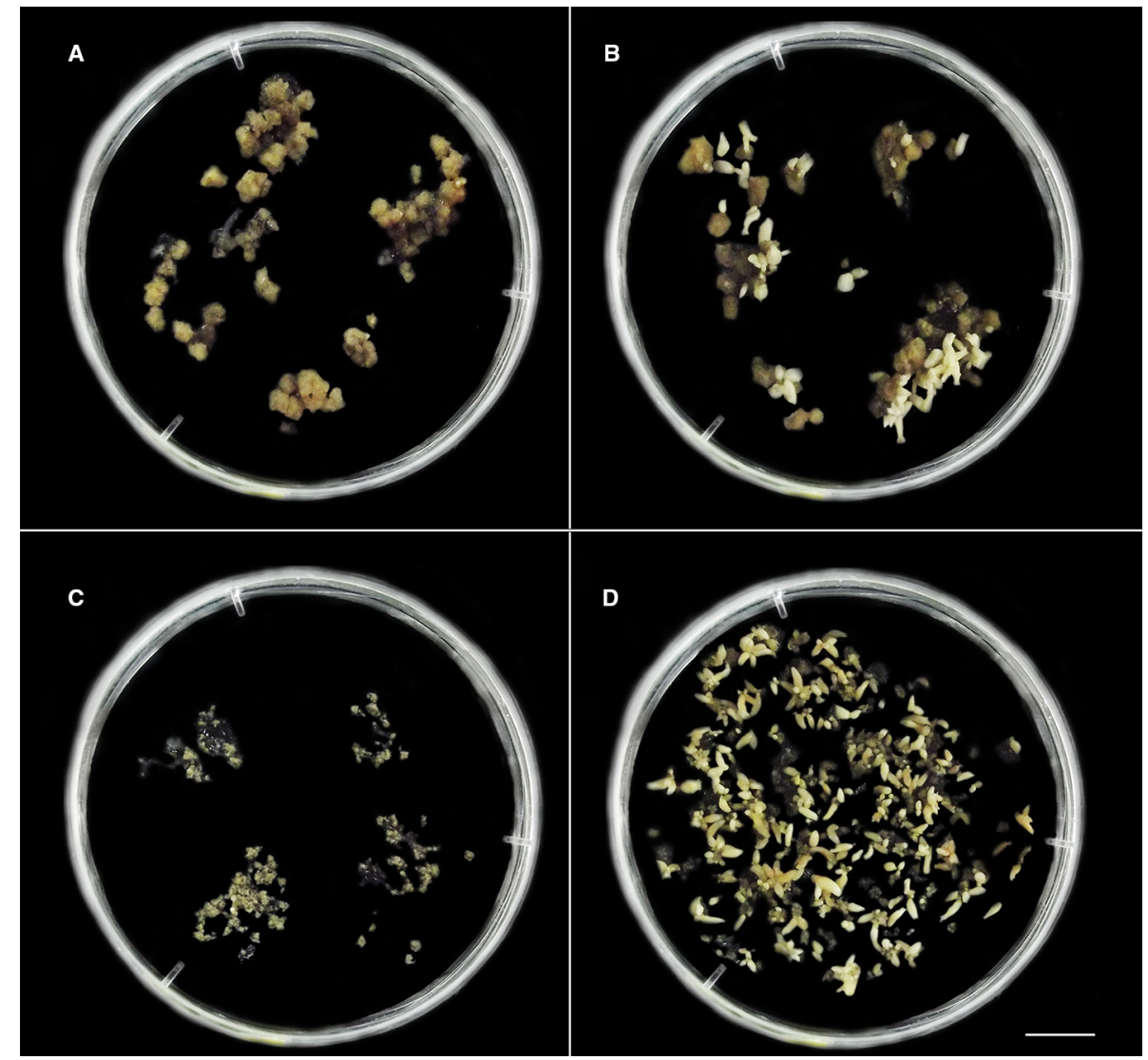

FIGURE 2 | The distinct in vitro responses from cellular mass of C. canephora (A, B) and C. arabica (C, D) observed after colchicine treatment in liquid medium M2 (Table 1, Figure 1). (A, B) C. canephora cellular mass after 150 days (Table 2) treated with $2.5 \mathrm{mM} / 48 \mathrm{~h}$ colchicine (Figure 1) and maintained in M4 medium (Table 1). (A) Petri dish showing predominance of unresponsive cellular mass and others with few globular somatic embryos (spotlight - right/above). (B) Petri dish exhibiting one unresponsive cellular mass and all others with somatic embryos in distinct development stages (globular, heart, torpedo, and cotyledonary). (C) Unresponsive cellular mass of $C$. arabica treated with $1.5 \mathrm{mM} / 72 \mathrm{~h}$ colchicine and maintained in $\mathrm{M} 4$ during 90 days. (D) Several $C$. arabica somatic embryos in different development stages. This result was obtained after 90 days from CAS treated with $0.5 \mathrm{mM} / 72 \mathrm{~h}$ colchicine and the resulting cellular mass maintained in M4. Bar $=1 \mathrm{~cm}$.

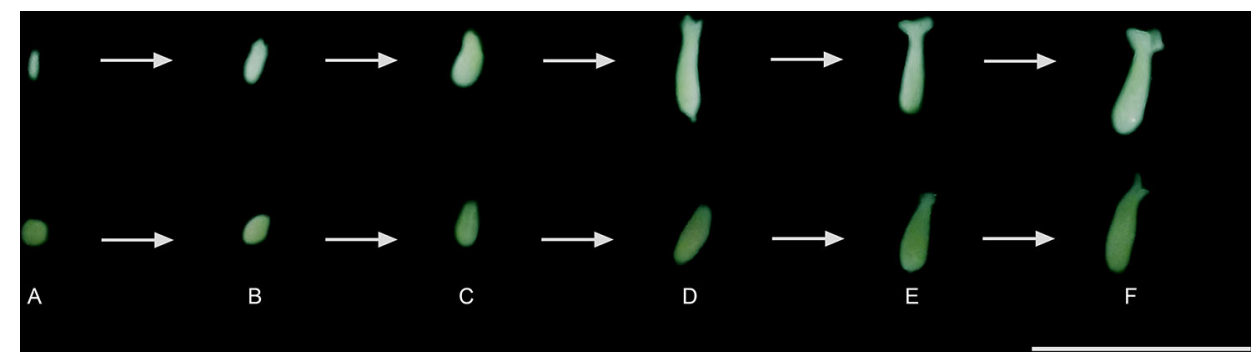

FIGURE 3 | Regeneration, conversion, and maturation of the somatic embryos of C. canephora and C. arabica: (A) globular, (B) heart, (C) torpedo, (D) initial, (E) middle, and (F) mature cotyledonary. The MCSE (F) were transferred to M5 (Table 1) and, thus, considered for comparison of the treatments. Bar $=1 \mathrm{~cm}$.

nuclei peak of the explant donor Coffea plant (Figure 4). For the recovered plantlets screened for CSD, the DNA ploidy level was newly determined after two months and after six months. So, the polyploid condition was verified for all Coffea plantlets (Table 2) in all flow cytometry analyses, confirming the solid polyploid condition. We found no mixoploid plantlets.

We screened plantlets with a DNA ploidy level equivalent to tetraploidy $(4 \mathrm{C}=2.86 \pm 0.053 \mathrm{pg}$ ) for C. canephora (explant 
TABLE 2 | Number of recovered MCSE, number (\%) of plantlets regenerated, and number (\%) of autotetraploid C. canephora and auto-alloctaploid C. arabica regenerated from the CSD procedure (Figure 1).

\begin{tabular}{|c|c|c|c|c|c|c|c|c|}
\hline Coffea species & $\begin{array}{l}\text { Colchicine } \\
\text { treatment }\end{array}$ & Medium $^{1}$ & $\begin{array}{l}\text { MCSE in } \\
90 \text { days }^{2}\end{array}$ & $\begin{array}{l}\text { MCSE in } \\
120 \text { days }^{2}\end{array}$ & $\begin{array}{l}\text { MCSE in } \\
150 \text { days }^{2}\end{array}$ & $\begin{array}{l}\text { Total of } \\
\text { MCSE }\end{array}$ & $\begin{array}{c}\text { Total of } \\
\text { plantlets }^{3}\end{array}$ & $\begin{array}{l}\text { Total }(\%) \text { of } \\
\text { plantlets with } \\
\text { chromosome } \\
\text { set doubling }\end{array}$ \\
\hline \multirow[t]{4}{*}{ C. canephora } & $2.5 \mathrm{mM} / 48 \mathrm{~h}$ & M3 & - & 25 & 100 & 125 & 45 (36.0\%) & 12 (26.7\%) \\
\hline & & M4 & - & 29 & 70 & 99 & 37 (37.4\%) & $16(43.2 \%)$ \\
\hline & $2.5 \mathrm{mM} / 72 \mathrm{~h}$ & M3 & - & 22 & 11 & 33 & 21 (63.6\%) & 8 (38.1\%) \\
\hline & & & & 76 & 181 & 257 & 103 (40.1\%) & 36 (34.9\%) \\
\hline \multirow[t]{3}{*}{ C. arabica } & $0.5 \mathrm{mM} / 72 \mathrm{~h}$ & M3 & 89 & 70 & 78 & 237 & 102 (43.0\%) & 27 (26.5\%) \\
\hline & & M4 & 235 & 40 & 109 & 384 & 187 (48.7\%) & 34 (18.2\%) \\
\hline & & & 324 & 110 & 187 & 621 & 289 (46.5\%) & 61 (21.1\%) \\
\hline
\end{tabular}

1-Table 1.

2-Total number and \% of MCSE regenerated in M3 or M4 and transferred to M5 (Table 1).

3-Total number and \% of plantlets showing leaves for DNA ploidy level assessment after two months in M5.

4-Number and \% of plantlets that showed the DNA ploidy level equivalent to the double in relation to the respective explant donor plant.

donor plant with $2 \mathrm{C}=1.43 \mathrm{pg}, 2 \mathrm{n}=2 \mathrm{x}=22$ chromosomes), being 12 plantlets (26.7\%) from $2.5 \mathrm{mM} / 48 \mathrm{~h} / \mathrm{M} 3,16(43.2 \%)$ from $2.5 \mathrm{mM} / 48 \mathrm{~h} / \mathrm{M} 4$, and 8 (38.1\%) from $2.5 \mathrm{mM} / 72 \mathrm{~h} / \mathrm{M} 3$. So, we found a total of 36 (34.9\%) tetraploid plantlets for $C$. canephora (Table 2). The tetraploidy of these plantlets was confirmed by chromosome counting, showing $2 \mathrm{n}=4 \mathrm{x}=44$ chromosomes. Therefore, these new germplasms represent $C$. canephora autotetraploids (Figure 4).

The CSD procedure (Figure 1) also provided octaploid plantlets of C. arabica (explant donor plant with $2 \mathrm{C}=2.62 \mathrm{pg}$, $2 \mathrm{n}=4 \mathrm{x}=44$ chromosomes). These plantlets, with $4 \mathrm{C}=5.24 \pm$ $0.028 \mathrm{pg}$ and $2 \mathrm{n}=8 \mathrm{x}=88$ chromosomes (Figure 4), were obtained from $0.5 \mathrm{mM} / 72 \mathrm{~h} / \mathrm{M} 3$ (27 plantlets-26.5\%) and M4 (34 plantlets-18.2\%). Thus, we screened a total of $61(21.1 \%)$ plantlets as octaploid for C. arabica (Table 2). Considering the evolutive origin of this species, which is a true allotetraploid from C. canephora $x$ C. eugenioides, and the ploidy level of the plantlets $(4 \mathrm{C}=5.24 \mathrm{pg}$ and $2 \mathrm{n}=8 \mathrm{x}=88)$, these germplasms can be considered as auto-alloctaploid.

No plantlets were recovered from the cellular masses that were not colchicine-treated or from other colchicine treatments. Due to these different in vitro responses (friable calli without MCSE and friable calli with MCSE), we evaluated genetic stability (using SSR markers) and global $5-\mathrm{mC} \%$ to verify if these differences are associated with DNA sequence (genetic stability) and/or 5-mC\% level (epigenetic) changes. Henceforth, the recovered somatic embryos were used as a parameter to define the responsiveness of the cellular masses.

\section{DNA Sequence Stability and 5-Methylcytosine Level}

The ten selected SSR primers, which were developed for C. arabica, amplified DNA sequences for the two Coffea explant donors and for all sampled cellular masses. One to six allelic forms were evidenced from the ten SSR primers. The primer SSRCa006 was monomorphic for the explant donor plants and all cellular masses for two Coffea species. The primer SSRCa091 was monomorphic only for C. arabica. The primers SSRCa084 and SSRCa091 were monomorphic for the responsive and non-responsive cellular masses treated with colchicine in C. canephora and primer SSRCa085 in C. arabica. Specifically, for C. arabica, only one cellular mass showed a different allelic form for primers SSRCa085, SSRCa088 and SSRCa095.

The primer SSRCa002 was the most polymorphic, evidencing six allelic forms for $C$. canephora and five for C. arabica. This primer amplified three allelic forms in not colchicine-treated cellular mass (friable calli of the M1) of C. canephora, and five in cellular mass treated with $2.5 \mathrm{mM}$ colchicine $/ 48 \mathrm{~h}$ and maintained in M3 and M4. For C. arabica, the same primer provided two alleles for not colchicine-treated cellular mass (friable calli of the M1), and three for the other cellular masses. This shows that for this primer, as well as for other primers, some alleles were specific for each Coffea species and for different cellular masses. Despite of the observed polymorphisms, there was no significant difference among the DNA sequences of the Coffea explant donors and the cellular masses, colchicine-treated or not, and with or without MCSE.

From these SSR polymorphisms, it was possible to verify that some allele forms were more common for the cellular mass with or without MCSE. The association of the found alleles with cellular masses was identified from the exploratory and descriptive correspondence statistical analysis. SSR045 allele 2 (SSR045_2), SSR002_6, SSR087_45, SSR088_2 were correlated to cellular mass with MCSE, and SSR045_3, SSR002_4 and SSR095_2 with cellular mass without MCSE. Therefore, the somaclonal variation occurred at DNA sequence level, which is demonstrated by emergence and disappearance of alleles verified in some sampled cellular masses, especially for the primers SSRCa002 and SSRCa045. However, its rates are not significant and do not explain the different responses of ISE among the cellular masses.

In the comparison of the mean values of global $5-\mathrm{mC} \%$ between $C$. canephora and C. arabica explant donor plants with the cellular masses, we were able to identify three different groups using Dunnett's test. In the first group, the mean $5-\mathrm{mC} \%$ values of the donor explant plants were statistically identical with $18.33 \%$ of C. canephora and $18.00 \%$ of C. arabica. In the second group, global methylation levels were slightly 


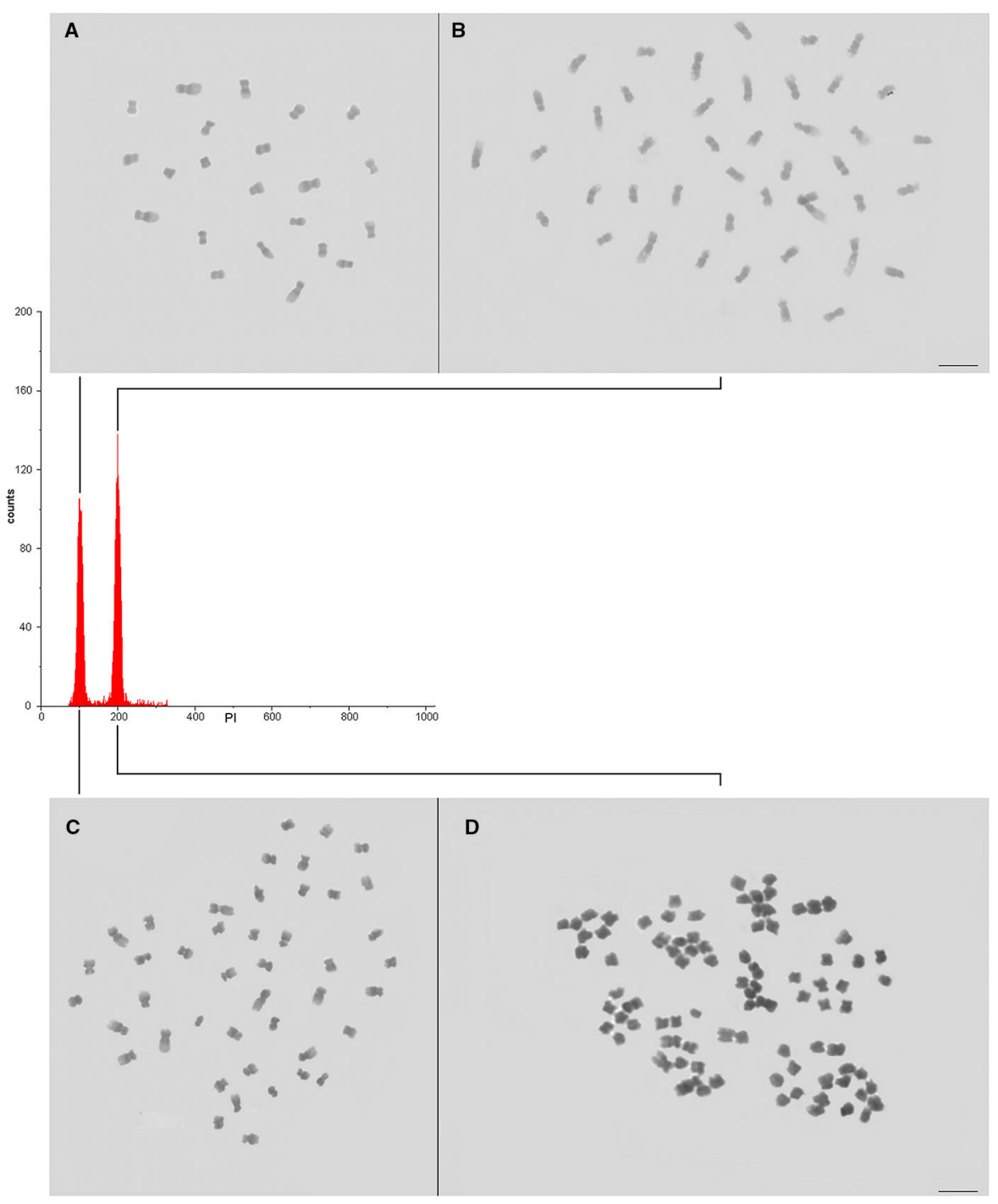

FIGURE 4 | Confirming the CSD of the Coffea CAS. (A, B) Nuclear DNA content and ploidy level of the diploid $(\mathbf{A}-$ explant donor plant, $2 \mathrm{C}=1.43$ pg, $2 x=22$ chromosomes) and autotetraploid (B-4C $=2.86 \mathrm{pg}, 4 \mathrm{x}=44$ chromosomes) C. canephora, and $(\mathbf{C}, \mathbf{D})$ tetraploid $(\mathbf{C}-$ explant donor plant, $2 \mathrm{C}=2.62$ pg, $4 \mathrm{x}=44$ chromosomes) and auto-alloctaploid ( $\mathbf{D}-4 \mathrm{C}=5.24 \mathrm{pg}, 8 \mathrm{x}=88$ chromosomes) $\mathrm{C}$. arabica. As the DNA ploidy level determination and nuclear genome size measurement were separately accomplished for $C$. canephora and for $C$. arabica, the channel of the internal standard (explant donor plant) $G_{0} / G_{1}$ nuclei peak was adjusted to 100. So, the $\mathrm{G}_{0} / \mathrm{G}_{1}$ nuclei peak of the autotetraploid C. canephora and auto-alloctaploid C. arabica occurred in channel 200.

reduced to $13.41 \%$ for C. canephora and $14.45 \%$ for C. arabica in the friable calli developed in M1 medium. In the third group, the global 5-mC\% was higher in the cellular masses than in the explant donor plants during somatic embryo recovering in M3 or M4, after colchicine treatments: $23.56 \%$ for C. canephora/2.5 $\mathrm{mM} / 48 \mathrm{~h} / \mathrm{M} 3$ or M4 without MCSE, $25.29 \%$ for C. canephora/2.5 $\mathrm{mM} / 48 \mathrm{~h} / \mathrm{M} 3$ or M4 with MCSE, $25.24 \%$ for C. arabica/1.5 mM/ 72 h/M3 or M4 without MCSE, $26.23 \%$ for C. arabica/0.5 mM/72 h/M3 with MCSE, and 29.13\% for C. arabica/0.5 mM/72 h/M4 with MCSE. Among them, the C. arabica/0.5 mM/72 h/M4 showed the highest mean value of global $5-\mathrm{mC} \%$ (Table S1).

\section{DISCUSSION}

In this study, a novel CSD procedure was established for two Coffea crop species from CAS of the diploid C. canephora and the true allotetraploid C. arabica, resulting in solid autotetraploid $C$. canephora $(2 \mathrm{n}=4 \mathrm{x})$ and auto-alloctaploid C. arabica $(2 \mathrm{n}=8 \mathrm{x})$ plantlets. These new germplasms were approximately regenerated within one year: 90 days for friable calli production, 67 days for CAS establishment, 2-4 days for colchicine treatment, 150 days for MCSE regeneration, and 60 days for plantlet recovery. This relative short time represents an 
advance in Coffea breeding programs, which depend on strategies that demand several crossings, large progeny and a long time to provide new germplasms. For instance, the in vitro hybrid selection time ( $~ 8$ years) is shorter than the hybrid selection time ( 25 years) in the traditional breeding program (Etienne et al., 2018). In addition, the new germplasms were formed from a simple and small leave fragment of the selected plants. Coffea leave cells showed a higher degree of plasticity, allowing them to reprogram and to form the somatic embryo and the plantlet from the following ISE in vitro morphogenic pathway: differentiated $\rightarrow$ dedifferentiated $\rightarrow$ redifferentiated.

To induce the polyploidization in liquid system, we explored the high proliferation of the Coffea CAS (van Boxtel and Berthouly, 1996; Clarindo et al., 2012). CAS are maintained in constant orbital agitation, allowing that more cells have direct contact with the compounds of the medium, mainly the growth regulators that promote cell proliferation (2,4-D in our study) and the antitubulin (here, the colchicine) during the CSD procedure, than in semisolid system (Loyola-Vargas and Vázquez-Flota, 2006; Dutt et al., 2010). In semisolid system, there is, for example, a reduction in the rate of nutrient diffusion due to the gelatinous consistency of the medium (Loyola-Vargas and Vázquez-Flota, 2006).

The key issue of the procedure (Figure 1) was the antitubulin treatment applied to proliferating CAS in liquid in vitro system. Again, the chemical and physical conditions of the tissue culture environment were effective, giving rise to friable calli (first stepdedifferentiation) and CAS with proliferative cells (second step), MCSE (third step) and plantlets with different ploidy level (fourth step). This ISE pathway has been extensively exploited for Coffea plantlet regeneration since van Boxtel and Berthouly (1996). In addition, it was reproducible for different species and genotypes of the same species (Samson et al., 2006; Almeida et al., 2008; Ibrahim et al., 2015), such as the diploid C. canephora and C. eugenioides, allotriploid "Híbrido de Timor" "CIFC 4106" and true allotetraploid C. arabica (Sanglard et al., 2019). Therefore, the obtained new Coffea germplasms are a statement that van Boxtel and Berthouly's (1996) in vitro conditions are the base to establish tissue culture protocols for this genus.

Coffea MCSE recovery occurred after removing the exogenous auxin 2,4-D and supplementing the tissue culture medium with activated charcoal. Thus, the elimination of the main chemical component responsible for keeping the cells in totipotent condition was required, as recommended by Rose et al. (2010) and Nic-Can and Loyola-Vargas (2016). Activated charcoal is added to tissue culture because of its adsorption capacity of exogenous 2,4-D residues (Pan and van Staden, 1998) and by adsorbing medium-inhibiting substances or toxic products released by cells, helping to promote the somatic embryo regeneration, conversion and maturation to mature cotyledonary. The osmotic control also is fundamental for somatic embryo recovery. For friable calli induction, CAS establishment and proliferation, a relatively high osmotic potential was necessary. On the order hand, the decrease of osmotic potential is fundamental for somatic embryo regeneration, mimetizing the seed environment during the zygotic embryo development (Dutt et al., 2010).

As summarized in Figure 5, the principle to promote the CSD was to polyploidize as many cells as possible of the Coffea CAS using the antitubulin colchicine, which may be replaced by another compound with the same and specific effect. The very specific (Planchais et al., 2000) and cytotoxic (Dutt et al., 2010; Acanda et al., 2015) antitubulin compounds hinder mitotic fuse formation, which is fundamental for chromatid segregation during anaphase and for cytokinesis. Considering this as well as the ploidy level, the number of chromosome sets in both Coffea species was duplicated due to the action of the anaphase promoting complex (APC)-activated separase pathway and prevention of cytokinesis. Separase (Esp1), a cysteine protease, cleaves the SCC1 subunit of the cohesin (Orr-Weaver, 1999; Tanaka et al., 1999), a protein complex constituted by conserved polypeptides SMC1, SMC3, SCC1 and SCC3 (Cai et al., 2003). This protein keeps the sister chromatids together (Orr-Weaver, 1999; Tanaka et al., 1999) from S-phase (interphase) to initial anaphase. As the polyploidization occurred in Coffea CAS, we concluded that the cohesin was cleaved, doubling the chromosome set number as in a normal anaphase. However, these chromosomes remained in the cell as a result of the absence of the mitotic fuse and, consequently, cytokinesis nonoccurrence. The nuclear membrane reorganization around these chromosomes happens in telophase, and daughter cells were formed with one nucleus in polyploid condition in comparison to the Coffea donor plant.

The colchicine application on the seventh day after the subculture also contributed to the generation of 36 (34.9\%) autotetraploid C. canephora and 61 (21.1\%) auto-alloctaploid C. arabica. For Citrus, Dutt et al. (2010) also treated the suspension cells with colchicine after seven days in the third subculture. Our results, as well as Dutt et al. (2010) and Zhang et al. (2007), highlight that the moment for antitubulin treatment should be chosen according to the number of cells in S-phase (interphase). This can be checked for each plant species using flow cytometry, for Coffea, this cell cycle phase occurs after 7 to 9 days (van Boxtel and Berthouly, 1996). In addition, this previous data increases experimental control and, consequently, the number of polyploids because it allows to attest that the cells are proliferative, to choose a day before mitosis and cytokinesis, and to conduct colchicine treatment in a shorter time.

Another impact of the CSD procedure was the recovery of pure polyploids of the both Coffea species. This result corroborates with the ISE possibility of regeneration of the somatic embryo and, consequently, a plantlet from only one cell of the friable calli (semisolid system, (Wu and Mooney, 2002; Petersen et al., 2003; Zhang et al., 2007; Sanglard et al., 2017) or CAS (liquid system, Dutt et al., 2010; Acanda et al., 2015). Moreover, CSD using proembryogenic cells of friable calli or CAS reduced or nulled the regeneration of mixoploid plantlets (Dutt et al., 2010; Acanda et al., 2015; Sanglard et al., 2017). Besides, CAS are considered meristematic cells, becoming a successful source for CSD and 


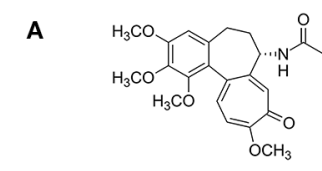

Colchicine

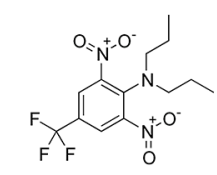

Trifluralin

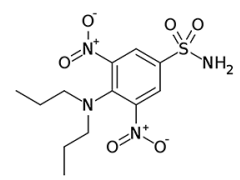

Oryzalin

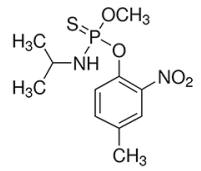

Amiprofos methyl

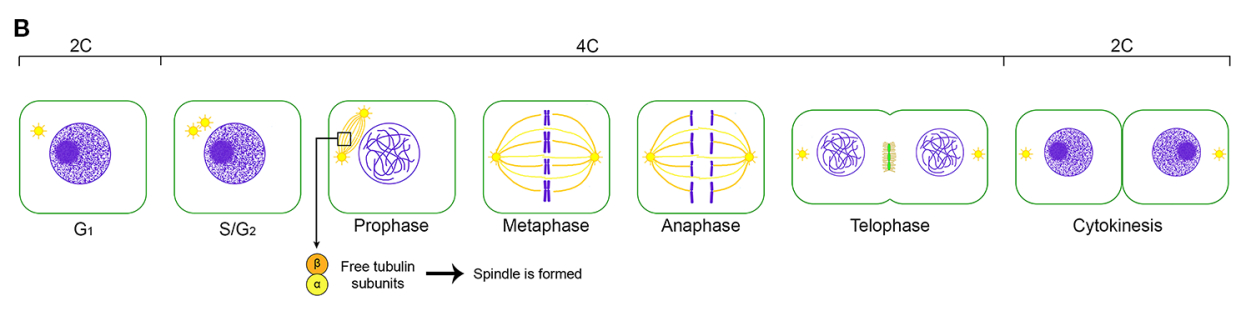

C
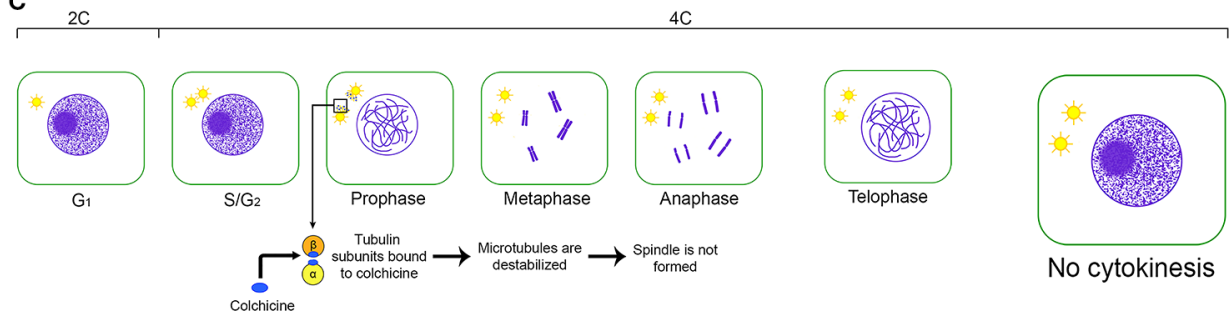

No cytokinesis

FIGURE 5 | The key issues of the CSD from a cell of the friable calli. (A) Chemical structure of the main antitubulin compounds used for CSD: colchicine-(S)-N(5,6,7,9-tetrahydro-1,2,3,10-tetramethoxy-9-oxobenzo[a]heptalen-7-yl)acetamide; oryzalin-3,5-dinitro- $\mathrm{N}^{4}, \mathrm{~N}^{4}$-dipropylsulfanilamide; trifluralin $\alpha, \alpha, \alpha$-trifluoro-2,6dinitro- $N, N$,-dipropyl-p-toluidine; and amiprofos methyl-O-methyl O-(2-nitro-p-tolyl) N-isopropylphosphoramidothionate. (B) Representation of the cell cycle without the interference of an antitubulinic agent, its cellular events and the changes of the relative DNA content (2C, $4 \mathrm{C})$ considering a diploid cell in $\mathrm{G}_{1}$. (C) The effect of the antitubulin agent on the cell cycle and, consequently, on the relative DNA content. Antitubulin agents prevent the mitotic fusion formation, avoiding the chromatide segregation and cytokynesis occurence. So, the chromosome set is duplicated in the same cell nuclei, which shows relative DNA content equivalent to $4 \mathrm{C}$ in $\mathrm{G}_{1}$.

providing solid polyploids. Therefore, the CAS can replace the shoot meristems in buds generally used for CSD (Dhooghe et al., 2011). CSD from the shoot apical meristem demands the polyploidization of all, or at least most, cells that constituted the periphery, central and medullar zones (L1, L2, and L3 layers). Therefore, mixoploids generated from this explant are result of the failure of the CSD.

Although the ISE is an advantageous system for CSD (Wu and Mooney, 2002; Petersen et al., 2003; Zhang et al., 2007; Sanglard et al., 2017), we also recorded cellular masses without somatic embryos and another with continuous somatic embryo regeneration, conversion and maturation. The first hypothesis to explain these ISE response divergences is the cytotoxic effect of the colchicine, but the non-colchicine treated cellular masses did not show somatic embryos. Besides, the responsive cellular masses of $C$. canephora were treated with $2.5 \mathrm{mM}$ colchicine, exactly the highest concentration of this compound. Acanda et al. (2015) related that the colchicine exposure reduced the embryogenic potential in comparison to the control. The same has been reported by several authors independently for biological material used for in vitro CSD.

Another possible explanation is the occurrence of somaclonal variation $(\mathrm{SV})$, which is a common phenomenon in cell culture caused by genetic and epigenetic changes in the nuclear genome, as well as genetic changes in organelle genomes (Kaeppler et al., 2000; Wang and Wang, 2012). Therefore, the term SV describes the variability produced by in vitro propagation due to physical and chemical conditions, time, and employed propagation system (liquid or semisolid). To test the hypothesis that SV occurred, we used SSR DNA markers to monitor cellular masses. We observed clonal fidelity in relation to the Coffea explant donors and used molecular markers.

Global 5-mC\% divergences were identified between the cellular masses in dependence of MCSE occurrence. In vitro plant cells were categorized in a genetic and evolutive context (Wang and Wang, 2012) according to the level and effect of the SV: true cells, neutral cells, deleterious cells and beneficial cells. The term true cell is designated for the in vitro cell without SV, but with the possibility of epigenetic modifications essential for the morphogenic process. A neutral cell is defined as the in vitro cell with SV, but having the same phenotype as the ancestral cell without changes in fitness. Neutral cells also include cells with deleterious SV but suppressed by other genome changes or by suppressor genes. Deleterious cells are defined as the in vitro cells containing SV, which leads to a decrease in the fitness relative to 
ancestral cell. Eventually, the beneficial cell is a cell exhibiting SV that increases the fitness value compared to ancestral cells. Based on these concepts by Wang and Wangs' (2012) and in our results, we concluded that the cellular masses of both Coffea species showed true and neutral cells. However, other aspects of the genome (as other molecular markers), epigenome (as the histone chemical change and $5-\mathrm{mC} \%$ of the genes), transcriptome and metabolome should be evaluated in future studies in order to understand the factors that have hindered the somatic embryo generation.

\section{CONCLUSION}

Our results suggest that the CSD using ISE and the antitubulin treatment of the CAS is a successful procedure to produce solid polyploid plants of Coffea and potentially for other species as well. We generated new Coffea germplasm, autotetraploid C. canephora and auto-alloctaploid C. arabica, that constituted a diversification of the in vitro germplasm of this genus. These individuals can be used as explant donor for other tissue culture procedures or be acclimatized for morphologic, physiologic and reproductive evaluations. Besides, the epigenetic modulation of the chromatin was associated to somatic embryo regeneration and, consequently, to plantlet recovery. Therefore, the tissue culture conditions should promote this typical change related to cellular redifferentiation.

\section{DATA AVAILABILITY STATEMENT}

The raw data supporting the conclusions of this article will be made available by the authors, without undue reservation, to any qualified researcher.

\section{REFERENCES}

Acanda, Y., Martínez, Ó., González, M. V., Jesús, M. P, and Rey, M. (2015). Highly efficient in vitro tetraploid plant production via colchicine treatment using embryogenic suspension cultures in grapevine (Vitis vinifera cv. Mencía). Plant Cell Tissue Organ Cult. 123, 547-555. doi: 10.1007/s11240-015-0859-3

Almeida, J. A. S., Silvarolla, M. B., Fazuoli, L. C., and Stancato, G. C. (2008). Embriogênese somática em genótipos de Coffea arabica L. Coffee Sci. 3, 143151. doi: $10.25186 /$ cs.v3i2.85

Blakesley, D., Allen, A., Pellny, T. K., and Roberts, A. V. (2002). Natural and induced polyploidy in Acacia dealbata Link. Acacia mangium Willd. Ann. Bot. 90, 391-398. doi: 10.1093/aob/mcf202

Blasco, M., Badenes, M. L., and Naval, M. M. (2015). Colchicine-induced polyploidy in loquat (Eriobotrya japonica (Thunb.) Lindl.). Plant Cell Tissue Organ Cult. 120, 453-461. doi: 10.1007/s11240-014-0612-3

Cai, X., Dong, F., Edelmann, R. E., and Makaroff, C. A. (2003). The Arabidopsis SYN1 cohesin protein is required for sister chromatid arm cohesion and homologous chromosome pairing. J. Cell Sci. 116, 2999-3007. doi: 10.1242/jcs.00601

Charrier, A., and Berthaud, J. (1985). "Botanical classification of coffee," in Coffee: botany, biochemistry, and broduction of beans and beverage. Eds. M. N. Clifforf and K. C. Willson (Croom Herm, Westport, London), 13-47.

Chen, Q., Tao, S., Bi, X., Xu, X., Wang, L., and Li, X. (2013). Research of total levels on DNA methylation in plant based on HPLC analysis. Am. J. Mol. Biol. 3, 98101. doi: 10.4236/ajmb.2013.32013

\section{AUTHOR CONTRIBUTIONS}

The authors LV, MM and WC conducted the tissue culture experiments and in vitro chromosome set doubling. WC carried out the cytogenetic and flow cytometry analyses. LV, PA-S and TS executed the SSR molecular analyses. LV, PA-S, and AP conducted epigenetic analyzes. LV, GC and AF did the statistical analysis. All authors equally contributed for manuscript editing and revision and approved the final manuscript for submission.

\section{ACKNOWLEDGMENTS}

We would like to thank Conselho Nacional de Desenvolvimento Científico e Tecnológico (CNPq, Brasília-DF, Brazil, grant: 443801/2014-2, 306870/2017-7, 312048/2018-1) and Fundação de Amparo à Pesquisa do Espírito Santo (FAPES, Vitória-ES, Brazil, grants: 65942604/2014 and 82/2017). This study was also financed in part by the Coordernação de Aperfeiçoamento de Pessoal de Nível Superior-Brasil (CAPES)—Finance Code 001.

\section{SUPPLEMENTARY MATERIAL}

The Supplementary Material for this article can be found online at: https://www.frontiersin.org/articles/10.3389/fpls.2020.00154/ full\#supplementary-material

TABLE S1 | Experimental design for DNA sequence variability and global DNA methylation level of individual cellular mass, and statistical comparison among the mean global 5-mC\%.

FIGURE S1 | Number of regenerated MCSE for C. canephora and C. arabica after 90, 120 and 150 days.

Clarindo, W. R., Carvalho, C. R., and Mendonça, M. A. C. (2012). Ploidy instability in long-term in vitro cultures of Coffea arabica L. monitored by flow cytometry. Plant Growth Regul. 68, 533-538. doi: 10.1007/s10725-012-9740-0

de Oliveira, S. C., Nunes, A. C., Carvalho, C. R., and Clarindo, W. R. (2013). In vitro polyploidization from shoot tips of Jatropha curcas L.: a biodiesel plant. Plant Growth Regul. 69, 79-86. doi: 10.1007/s10725-012-9749-4

Dhooghe, E., van Laere, K., Eeckhaut, T., Leus, L., and van Huylenbroeck, J. (2011). Mitotic chromosome doubling of plant tissues in vitro. Plant Cell Tissue Organ Cult. 104, 359-373. doi: 10.1007/s11240-010-9786-5

Doyle, J. J., and Doyle, J. L. (1990). Isolation of plant DNA from fresh tissue. Focus $12,13-15$

Dutt, M., Vasconcellos, M., Song, K. J., Gmitter, F. G., and Grosser, J. W. (2010). In vitro production of autotetraploid Ponkan mandarin (Citrus reticulata Blanco) using cell suspension cultures. Euphytica 173, 235-242. doi: 10.1007/s10681-009-0098-y

Eeckhaut, T. G., Werbrouck, S. P., Leus, L. W., et al. (2004). Chemically induced polyploidization in Spathiphyllum wallisii Regel through somatic embryogenesis. Plant Cell Tissue Organ Cult. 78, 241-246. doi: 10.1023/B: TICU.0000025659.19232.04

Etienne, H., Breton, D., Breitler, J.-C., Bertrand, B., Déchamp, E., Awada, R., et al. (2018). Coffee somatic embryogenesis: how did research, experience gained and innovations promote the commercial propagation of elite clones from the two cultivated species? Front. Plant Sci. 9, 1-21. doi: 10.3389/fpls.2018.01630

Farah, A., and Donangelo, C. M. (2006). Phenolic compounds in coffee. Braz. J. Plant Physiol. 18, 23-36. doi: 10.1590/S1677-04202006000100003 
Fu, L., Zhu, Y., Li, M., and Sun, H. (2019). Autopolyploid induction via somatic embryogenesis in Lilium distichum Nakai and Lilium cernuum Komar. Plant Cell Tissue Organ Cult. 139, 237-248. doi: 10.1007/s11240-019-01671-x

Galbraith, D. W., Harkins, K. R., Maddox, J. M., Ayres, N. M., Sharma, D. P., and Firoozabady, E. (1983). Rapid flow cytometric analysis of the cell cycle in intact plant tissues. Science 220, 1049-1051. doi: 10.1126/science.220.4601.1049

Gamborg, O. L., Miller, R. A., and Ojima, K. (1968). Nutrient requirement of suspension cultures of soybean root cells. Exp. Cell Res. 50, 151-158. doi: 10.1016/0014-4827(68)90403-5

Iannicelli, J., Guariniello, J., Tossi, V. E., Regalado, J. J., Di Ciaccio, L., van Baren, C. M., et al. (2020). The "polyploid effect" in the breeding of aromatic and medicinal species. Sci. Hortic. 260, 108854. doi: 10.1016/j.scienta.2019.108854

Ibrahim, M. S. D., Hartati, R. R. S., Rubiyo, R., Purwito, A., and Sudarsono, S. (2015). The induction of primary and secondary somatic embryo to support Arabica coffee propagation. J. Trop. Crop Sci. 2, 3. doi: 10.29244/jtcs.2.3.6-13

Kaeppler, S. M., Kaeppler, H. F., and Rhee, Y. (2000). Epigenetic aspects of somaclonal variation in plants. Plant Mol. Biol. 43, 179-188. doi: 10.1023/A:1006423110134

Li, M., Guo, Y., Liu, S., Zhao, Y., Pang, X., and Li, Y. (2019). Autotetraploidization in Ziziphus jujuba Mill. var. spinosa enhances salt tolerance conferred by active, diverse stress responses. Environ. Exp. Bot. 165, 92-107. doi: 10.1016/j.envexpbot.2019.05.016

Liu, G., Li, Z., and Bao, M. (2007). Colchicine-induced chromosome doubling in Platanus acerifolia and its effect on plant morphology. Euphytica 157, 145-154. doi: 10.1007/s10681-007-9406-6

Loyola-Vargas, V. M., and Vázquez-Flota, F. (2006). An introduction to plant cell culture: back to the future. Methods Mol. Biol. 318, 3-8. doi: 10.1385/1-59259-959-1:003

Mallet, J. (2007). Hybrid speciation. Nature 446, 279-283. doi: 10.1038/ nature 05706

Missio, R. F., Caixeta, E. T., Zambolim, E. M., Zambolim, L., and Sakiyama, N. S. (2009). Development and validation of SSR markers for Coffea arabica L. Crop Breed. Appl. Biotechnol. 9, 361-371. doi: 10.12702/1984-7033.v09n04a11

Murashige, T., and Nakano, R. (1966). Tissue culture as a potential tool in obtaining polyploid plants. J. Hered. 57, 114-118. doi: 10.1093/oxfordjournals.jhered.a107486

Murashige, T., and Skoog, F. (1962). A revised medium for rapid growth and bio assays with tobacco tissue cultures. Physiol. Plant 15, 473-497. doi: 10.1111/ j.1399-3054.1962.tb08052.x

Nic-Can, G. I., and Loyola-Vargas, V. M. (2016). "The role of the auxins during somatic embryogenesis," in Somatic Embryogenesis: Fundamental Aspects and Applications. Eds. V. M. Loyola-Vargas and N. Ochoa-Alejo (Switzerland: Springer International Publishing), 171-182. doi: 10.1007/978-3-319-33705-0_10

Orr-Weaver, T. L. (1999). The ties that bind: localization of the sister-chromatid cohesin complex on yeast chromosomes. Cell 99, 1-4. doi: 10.1016/S0092-8674(00)80055-0

Otto, F. J. (1990). "DAPI staining of fixed cells for high-resolution flow cytometry of nuclear DNA," in Methods in cell biology, vol. 33 . Eds. Z. Darzynkiewiez, H. A. Crissman and J. P. Robinson (San Diego: Academic Press), 105-110.

Pan, M. J., and van Staden, J. (1998). The use of charcoal in in vitro culture: a review. Plant Growth Regul. 26, 155-163. doi: 10.1023/A:1006119015972

Petersen, K. K., Hagberg, P., and Kristiansen, K. (2003). Colchicine and oryzalin mediated chromosome doubling in different genotypes of Miscanthus sinensis. Plant Cell Tissue Organ Cult. 73, 137-146. doi: 10.1023/A:1022854303371

Planchais, S., Glab, N., Inzé, D., and Bergounioux, C. (2000). Chemical inhibitors: a tool for plant cell cycle studies. FEBS Lett. 476, 78-83. doi: 10.1016/s00145793(00)01675-6

Praça-Fontes, M. M., Carvalho, C. R., and Clarindo, W. R. (2011). C-value reassessment of plant standards: an image cytometry approach. Plant Cell Rep. 30, 2303-2312. doi: 10.1007/s00299-011-1135-6

Rose, R. J., Mantiri, F. R., Kurdyukov, S., Chen, S. K., Wang, X. D., Nolan, K. E., et al. (2010). "Developmental biology of somatic embryogenesis," in Plant developmental biology-biotechnological perspectives. Eds. E. C. Pua and M. R. Davey (Berlin, Heidelberg: Springer), 3-26. doi: 10.1007/978-3-642-04670-4_1

Samson, N. P., Campa, C., Gal, L. L., Noirot, M., Thomas, G., Lokeswari, T. S., et al. (2006). Effect of primary culture medium composition on high frequency somatic embryogenesis in different Coffea species. Plant Cell Tissue Organ Cult. 86, 37-45. doi: 10.1007/s11240-006-9094-2
Sanglard, N. A., Amaral-Silva, P. M., Sattler, M. C., de Oliveira, S. C., Nunes, A. C. P., Soares, T. C. B., et al. (2017). From chromosome doubling to DNA sequence changes: outcomes of an improved in vitro procedure developed for allotriploid Híbrido de Timor (Coffea arabica L. $\times$ Coffea canephora Pierre ex A. Froehner). Plant Cell Tissue Organ 131, 223-231. doi: 10.1007/ s11240-017-1278-4

Sanglard, N. A., Amaral-Silva, P. M., Sattler, M. C., de Oliveira, S. C., Cesário, L. M., Ferreira, A., et al. (2019). Indirect somatic embryogenesis in Coffea with different ploidy levels: a revisiting and updating study. Plant Cell Tissue Organ 136, 255-267. doi: 10.1007/s11240-018-1511-9

Sattler, M. C., Carvalho, C. R., and Clarindo, W. R. (2016). The polyploidy and its key role in plant breeding. Planta 243, 281-296. doi: 10.1007/s00425-0152450-x

Shi, Q., Liu, P., Wang, J., Xu, J., Ning, Q., and Liu, M. (2015). A novel in vivo shoot regeneration system via callus in woody fruit tree Chinese jujube (Ziziphus jujuba Mill.). Sci. Hortic. 188, 30-35. doi: 10.1016/j.scienta. 2015.03.013

Silva, A. J., Carvalho, C. R., and Clarindo, W. R. (2019). Chromosome set doubling and ploidy stability in synthetic auto- and allotetraploid of Eucalyptus: from in vitro condition to the field. Plant Cell Tissue Organ Cult. 138, 387-394. doi: 10.1007/s11240-019-01627-1

Soltis, D. E., Albert, V. A., Leebens-Mack, J., Bell, C. D., Paterson, A. H., Zheng, C., et al. (2009). Polyploidy and angiosperm diversification. Am. J. Bot. 96, 336348. doi: 10.3732/ajb.0800079

Stebbins, G. L. (1947). Types of polyploids: their classification and significance. Adv. Genet. 1, 403-429. doi: 10.1016/S0065-2660(08)60490-3

Stewart, F. C., Mapes, M. O., and Mears, K. (1958). Growth and organized development of cultured cells. II. Organization in cultures grown from freely suspended cells. Am. J. Bot. 45, 705-708. doi: 10.1002/j.1537-2197.1958. tb10599.x

Tanaka, T., Cosma, M. P., Wirth, K., and Nasmyth, K. (1999). Identification of cohesin association sites at centromeres and along chromosome arms. Cell 98, 847-858. doi: 10.1016/s0092-8674(00)81518-4

van Boxtel, J., and Berthouly, M. (1996). High frequency somatic embryogenesis from coffee leaves. Plant Cell Tissue Organ Cult. 44, 7-17. doi: 10.1007/ BF00045907

Wang, Q. M., and Wang, L. (2012). An evolutionary view of plant tissue culture: somaclonal variation and selection. Plant Cell Rep. 31, 1535-1547. doi: 10.1007/s00299-012-1281-5

$\mathrm{Wu}, \mathrm{J}$, and Mooney, P. (2002).Autotetraploid tangor plant regeneration from in vitro Citrus somatic embryogenic callus treated with colchicine. Plant Cell Tissue Organ Cult. 70, 99-104. doi: 10.1023/A:1016029829649

Xie, X., Agüero, C. B., Wang, Y., and Walker, M. A. (2015). In vitro induction of tetraploids in Vitis $\times$ Muscadinia hybrids. Plant Cell Tissue Organ Cult. 122, 675-683. doi: 10.1007/s11240-015-0801-8

Yu, Q., Guyot, R., Kochko, A., Byers, A., Navajas-Pérez, R., Langston, B. J., et al. (2011). Micro-collinearity and genome evolution in the vicinity of an ethylene receptor gene of cultivated diploid and allotetraploid coffee species (Coffea). Plant J. 67, 305-317. doi: 10.1111/j.1365-313X.2011.04590.x

Zhang, J., Zhang, M., and Deng, X. (2007). Obtaining autotetraploids in vitro at a high frequency in Citrus sinensis. Plant Cell Tissue Organ Cult. 89, 211-216. doi: $10.1007 / \mathrm{s} 11240-007-9240-5$

Conflict of Interest: The authors declare that the research was conducted in the absence of any commercial or financial relationships that could be construed as a potential conflict of interest.

Copyright $\odot 2020$ Venial, Mendonça, Amaral-Silva, Canal, Passos, Ferreira, Soares and Clarindo. This is an open-access article distributed under the terms of the Creative Commons Attribution License (CC BY). The use, distribution or reproduction in other forums is permitted, provided the original author(s) and the copyright owner(s) are credited and that the original publication in this journal is cited, in accordance with accepted academic practice. No use, distribution or reproduction is permitted which does not comply with these terms. 